\title{
Botulinum Toxin in the Field of Dermatology: Novel Indications
}

\author{
Yoon Seob Kim, Eun Sun Hong and Hei Sung Kim * \\ Department of Dermatology, Incheon St. Mary's Hospital, College of Medicine, \\ The Catholic University of Korea, Seoul 06591, Korea; kysbbubbu@hotmail.com (Y.S.K.); \\ dmsun99@gmail.com (E.S.H.) \\ * Correspondence: hazelkimhoho@gmail.com; Tel.: +82-32-280-5105; Fax: +82-32-506-9514 \\ Academic Editor: Siro Luvisetto \\ Received: 20 November 2017; Accepted: 14 December 2017; Published: 16 December 2017
}

\begin{abstract}
Since its approval by the US Food and Drug Administration in 2002 for glabellar wrinkles, botulinum toxin (BTX) has been widely used to correct facial wrinkles. As a result, many consider BTX synonymous with cosmetic dermatology. Recent studies indicate that BTX elicits biological effects on various skin cell types via the modulation of neurotransmitter release, and it seems that BTX has a wider zone of dermatologic influence than originally understood. Clinicians and researchers are now beginning to explore the potential of BTX beyond the amelioration of facial lines and encouraging results are seen with BTX in a variety of skin conditions. In this paper, we review novel dermatological indications of BTX which includes (but not limited to) scar prevention, facial flushing, post-herpetic neuralgia and itch. These areas show great promise, but there is definite need for larger, double-blinded, randomized control trials against established treatments before BTX becomes a clinical reality.
\end{abstract}

Keywords: botulinum toxin; biological effect; various cell types; neurotransmitter; dermatology; novel indication

\section{Introduction}

Botulinum toxin (BTX) is a potent neurotoxin produced by the bacterium Clostridium botulinum. Seven distinct isoforms (BTX-A, B, C, D, E, F, and G) have been described, with BTX-A and BTX-B being commercially available. BTX blocks the release of acetylcholine and a number of other neurotransmitters from presynaptic vesicles by deactivating SNARE proteins and has a long history of therapeutic application in neurological conditions with a strong efficacy and safety profile. As widely known, the skin interacts with the nervous system and there is increasing evidence that the neurological system directly participates in cutaneous inflammation and wound healing [1,2]. With that said, BTX has been used experimentally in a number of dermatological conditions which include scar prevention, facial flushing, post-herpetic neuralgia and itch with good results. The general mechanism which underlies these novel indications includes suppression of mast cell activity, and the inhibition of substance $\mathrm{P}$, calcitonin gene-related peptide (CGRP) and glutamate release. In this review, we analyze the possible off-label applications of BTX based on published data.

\section{Off-Label Use of BTX in Dermatology}

\subsection{BTX in Hypertrophic Scar Treatment}

Scars are defined as marks that remain after the healing of a wound. They cause significant cosmetic concern, especially when located on conspicuous areas such as the head and neck. 
Hypertrophic scars and keloids represent an aberrant response to the wound healing process and are characterized by dysregulated growth and excessive collagen formation [3].

BTX has been reported as a treatment measure for hypertrophic scars and keloids in a number of studies [4-7] (Table 1). In one study [4], BTX injection $\left(2.5 \mathrm{IU} / \mathrm{cm}^{3}\right)$ was performed once a month for three months, leading to a significant decrease in erythema, itching, and pliability of the scar. In another study [7], 12 keloid patients received BTX injection (70-140 IU per session, every 3 months for a maximum of 9 months) and achieved more than $50 \%$ improvement in symptoms, size, height, and induration of the scar. In a randomized controlled trial (RCT) [5], the efficacy of BTX (5 IU / $\mathrm{cm}^{3}$, 3 sessions, repeated every 8 weeks) was compared with that of steroid injection (triamcinolone, kenacort $10 \mathrm{mg} / \mathrm{cc}, 6$ sessions, repeated every 4 weeks) in keloids, where BTX led to a more significant reduction of subjective complaints (itch and pain of the scar).

The molecular mechanism of BTX on hypertrophic scars and keloids is not yet perfectly explained, but BTX has been shown to inhibit the proliferation of fibroblasts derived from hypertrophic scar tissues. In addition, BTX is reported to suppress the expression of transforming growth factor (TGF)- $\beta 1$, collagen I and III, $\alpha$-smooth muscle actin and myosin II protein in keloid fibroblasts [8-11].

One particularly favorable aspect of BTX is its ability to control the subjective symptoms of hypertrophic scars. BTX can immobilize the local muscles of a scar and reduce skin tension caused by the muscle pull [12]. This relieves trapped nerve fibers in keloids, neutralizing the itch and pain associated with small-fiber neuropathy [13]. Another advantage of BTX is the absence of skin atrophy and telangiectasia which is often seen after steroid injection.

The limitations of BTX on hypertrophic scars and keloids would be the high cost of the drug (with the dosages mentioned in prior studies) and its potential effect on the surrounding muscles. Due to these limitations, many suggest the use of BTX as an adjuvant rather than first line treatment for hypertrophic scars.

\subsection{BTX in Scar Prevention}

Nowadays, many acknowledge the role of active scar prevention important in post-operative scar management. A key factor that determines the final cosmetic appearance of a surgical scar is the tension that acts on the wound edges during the healing phase [14,15]. By blocking acetylcholine neurotransmitter release from peripheral nerves, BTX allows near-complete elimination of dynamic muscle tension on the healing wound. The tension relieving properties, together with the direct inhibitory effects of BTX on fibroblasts and TGF- $\beta 1$ expression support its usage in surgical scar prevention [16-18]. The anti-inflammatory effect of BTX and its action of the cutaneous vasculature calms down the inflammatory phase (immediate to $2-5$ days) of the wound healing process which may also contribute to scar prevention.

A number of studies have reported the effectiveness of BTX in scar prevention [19-22] (Table 2). In a split-scar RCT [19], the safety and efficacy of early postoperative BTX injection was assessed in 15 thyroidectomy scar patients. A single treatment with either BTX (20-65 IU) or $0.9 \%$ saline (control) was applied to fresh scars (within 10 days of thyroidectomy), where the BTX-treated halves showed a significantly better outcome in terms of scar scales and patient satisfaction compared to the saline treated sides. In 2006, Gassner [21] tested whether postoperative injection of BTX improved facial scars following forehead lacerations and excisions. BTX (15-45 IU) was injected to post-op scars within $24 \mathrm{~h}$ after wound closure to produce enhanced wound healing and improved cosmesis compared to placebo (normal saline) injection.

BTX is best used for op scars. It would be optimal to inject BTX intraoperatively or shortly (preferably within days) after the surgery. To note, BTX should be avoided in open wounds as it delays wound closure. 
Table 1. Representative studies of botulinum toxin (BTX) in hypertrophic scar treatment.

\begin{tabular}{|c|c|c|c|c|c|c|}
\hline $\begin{array}{l}\text { First Author } \\
\text { [Ref.], Year }\end{array}$ & Type of Study & $n$ & Treatment Regimen & Outcome Measures & Follow-Up & Results (Including Adverse Effects) \\
\hline $\begin{array}{l}\text { Elhefnawy [4], } \\
2016\end{array}$ & $\begin{array}{l}\text { Prospective, single } \\
\text { arm (BTX) }\end{array}$ & 20 & $\begin{array}{l}\text { BTX once a month for } 3 \text { months. } \\
\text { BTX concentration: } 5 \mathrm{IU} / 0.1 \mathrm{~mL} \text {; } \\
\text { Injected dose: } 2.5 \mathrm{IU} / \mathrm{cm}^{3} \\
\text { not exceeding } 100 \mathrm{IU} / \text { session }\end{array}$ & $\begin{array}{l}\text { Overall assessment made by } \\
\text { the patient and physician } \\
\text { (5-point scale). Lesions were } \\
\text { assessed for erythema, } \\
\text { itching, and pliability; each } \\
\text { item was assessed on a } \\
\text { 5-point scale }\end{array}$ & 6 months & $\begin{array}{l}\text { Therapeutic satisfaction was "good" in } 14 \text { patients, } \\
\text { "excellent" in 6; The mean erythema score decreased } \\
\text { from } 3.2 \text { to } 1.0 \text {, mean pliability score from } 3.3 \text { to } 0.8 \text { and } \\
\text { the mean itching score from } 2.7 \text { to } 0.7 \text {; All findings were } \\
\text { statistically significant. } \\
\text { No recurrence or complications. }\end{array}$ \\
\hline $\begin{array}{l}\text { Shaarawy [5], } \\
2015\end{array}$ & $\begin{array}{l}\text { Randomized, } \\
\text { double-blinded, } \\
\text { comparative study } \\
\text { (BTX vs. IL steroid } \\
\text { injection) }\end{array}$ & 24 & $\begin{array}{l}\text { Group A (12 patients; } \\
\text { Triamcinolone, Kenacort } \\
10 \mathrm{mg} / \mathrm{cc} \text {; repeated every } 4 \text { weeks } \\
\text { for } 6 \text { sessions/or till complete } \\
\text { remission) } \\
\text { Group B ( } 12 \text { patients; } \\
\text { BTX } 5 \mathrm{IU} / \mathrm{cm}^{3} \text { repeated every } \\
8 \text { weeks for three sessions/or till } \\
\text { complete remission of keloid) }\end{array}$ & $\begin{array}{l}\text { Objective parameters } \\
\text { (hardness, elevation, and } \\
\text { redness) and subjective } \\
\text { complaints (itching, pain and } \\
\text { tenderness) on a scale of 0-3; } \\
\text { Volume of keloid; Patient } \\
\text { satisfaction (3-point scale) }\end{array}$ & 7 months & $\begin{array}{l}\text { Significant decrease in scar volume after treatment with } \\
\text { a volume reduction of } 82.7 \% \text { (group A) and } 79.2 \% \\
\text { (group B). Significant softening, significant decrease in } \\
\text { height and significant decrease in redness with little } \\
\text { difference between the groups. All patients mentioned } \\
\text { a significant reduction of their subjective complaints } \\
\text { which was more prominent in group B (BTX group). } \\
\text { Skin atrophy and telangiectasia was evident in } \\
3 \text { patients of group A. }\end{array}$ \\
\hline Xiao [6], 2009 & $\begin{array}{l}\text { Prospective, single } \\
\text { arm (BTX) }\end{array}$ & 19 & $\begin{array}{l}\text { BTX once a month for a total of } \\
3 \text { months. BTX injection dose: } \\
2.5 \mathrm{IU} / \mathrm{cm}^{3} \text {, not exceeding } \\
100 \mathrm{IU} / \text { session. }\end{array}$ & $\begin{array}{l}\text { Physician and patient } \\
\text { satisfaction (5-point scale); } \\
\text { Clinical symptoms in terms } \\
\text { of erythema, pliability and } \\
\text { itching sensation (each } \\
\text { graded on a 5-point scale) }\end{array}$ & 6 months & $\begin{array}{l}\text { Patient satisfaction: good (63.1\%), excellent ( }(36.8 \%) \\
\text { Physician satisfaction: good }(78.9 \%) \text {, excellent }(10.5 \%) \\
\text { Mean erythema score decreased from } 3.41 \text { to } 1.23 \text {; } \\
\text { The pliability score decreased from } 3.85 \text { to } 0.78 \text {; and the } \\
\text { itching score decreased from } 3.50 \text { to } 0.83 \text {. All reductions } \\
\text { were statistically significant. } \\
\text { Besides the injection pain, no other complication was } \\
\text { detected in this study. }\end{array}$ \\
\hline Zhibo [7], 2009 & $\begin{array}{l}\text { Prospective, single } \\
\text { arm (BTX) }\end{array}$ & 12 & $\begin{array}{l}\text { BTX at } 3 \text { months interval for a } \\
\text { maximum of } 9 \text { months. BTX } \\
\text { concentration: } 35 \mathrm{IU} / \mathrm{mL} \text {; injected } \\
\text { dose: } 70-140 \mathrm{IU} / \text { session }\end{array}$ & $\begin{array}{l}\text { Improvement was judged } \\
\text { based on a decrease in size } \\
\text { and flattening of the lesion } \\
\text { with a 5-point scale; Patient } \\
\text { satisfaction }\end{array}$ & 1 year & $\begin{array}{l}\text { Therapeutic outcome: excellent }(25 \%) \text {, good }(41.7 \%) \text {, } \\
\text { fair }(33.3 \%) \text {. } \\
\text { The level of patient satisfaction was very high. } \\
\text { There were no serious adverse sequelae. }\end{array}$ \\
\hline
\end{tabular}

BTX: Onabotulinum toxin unless otherwise stated, IL: intra-lesional. 
Table 2. Representative studies of BTX in scar prevention.

\begin{tabular}{|c|c|c|c|c|c|c|}
\hline $\begin{array}{l}\text { First Author } \\
\text { [Ref.], Year }\end{array}$ & Type of Study & $n$ & Treatment Regimen & Outcome Measures & Follow-Up & Results (Including Adverse Effects) \\
\hline Kim [19], 2014 & $\begin{array}{l}\text { A split-scar, } \\
\text { double-blind, RCT } \\
\text { (BTX vs. saline) }\end{array}$ & 15 & $\begin{array}{l}\text { Treatment with either BTX or } \\
0.9 \% \text { normal saline on scar } \\
\text { halves. A single treatment } \\
\text { delivered within } 10 \text { days of } \\
\text { thyroidectomy. BTX } \\
\text { concentration: } 5 \mathrm{IU} / \mathrm{mL} \text {; } \\
\text { Injection dose: } 20-65 \mathrm{IU}\end{array}$ & $\begin{array}{l}\text { Modified Stony Brook Scar } \\
\text { Evaluation Scale (SBSES) } \\
\text { Patient satisfaction } \\
\text { (4-point scale) }\end{array}$ & 6 months & $\begin{array}{l}\text { A significant improvement in SBSES score was noted } \\
\text { for the BTX-treated halves ( } p<0.001) \text {, with minimal } \\
\text { change on the saline-treated side. The mean calculated } \\
\text { difference in SBSES scores (final/initial) between the } \\
\text { BTX-treated side and the saline-treated side was also } \\
\text { significant }(p<0.001) \text {. } \\
\text { Subjects were significantly more satisfied with the } \\
\text { overall outcome of the BTX-treated side at } 6 \text { months' } \\
\text { follow-up, according to a four-point grading scale } \\
(p=0.000 ; 95 \% \text { CI } 1.24 \text { to } 2.36)\end{array}$ \\
\hline Ziade [20], 2013 & $\begin{array}{l}\text { RCT (BTX vs. no } \\
\text { injection) }\end{array}$ & $\begin{array}{l}\text { BTX group: } 15 \\
\text { (4 lost for FU) } \\
\text { Control group: } \\
15 \text { (2 lost for FU) }\end{array}$ & $\begin{array}{l}\text { BTX group: A single } \\
\text { treatment delivered within } \\
72 \mathrm{~h} \text { following op. BTX } \\
\text { concentration: } 10 \mathrm{IU} / \mathrm{mL} \text {; } \\
\text { Injection dose: } 15-40 \mathrm{IU} \text {. } \\
\text { Control group: No injection }\end{array}$ & $\begin{array}{l}\text { Patient Scar Assessment } \\
\text { Scale (PSAS) } \\
\text { Observer Scar Assessment } \\
\text { Scale (OSAS) } \\
\text { Vancouver Scar Scale (VSS), } \\
\text { Visual Analogue Scale (VAS) }\end{array}$ & 12 months & $\begin{array}{l}\text { No statistically significant differences were found } \\
\text { between the two groups for the PSAS, OSAS and } \\
\text { VSS scores. } \\
\text { The median VAS rated by the six evaluators was } 8.25 \\
\text { for the botulinum toxin-treated group compared with } \\
6.35 \text { for the control group }(p<0.001) \text {. }\end{array}$ \\
\hline $\begin{array}{l}\text { Gassner [21], } \\
2006\end{array}$ & RCT (BTX vs. saline) & $\begin{array}{l}\text { BTX group: } 22 \\
\text { (6 excluded) } \\
\text { Control group: } \\
20 \text { ( } 5 \text { excluded })\end{array}$ & $\begin{array}{l}\text { BTX group: A single injection } \\
\text { within } 24 \mathrm{~h} \text { after wound } \\
\text { closure. BTX concentration: } \\
75 \mathrm{IU} / \mathrm{mL} \text {; Injection dose: } \\
15-45 \mathrm{IU} \text {. Control group: A } \\
\text { single injection within } 24 \mathrm{~h} \\
\text { after wound closure. } \\
\text { Injection dose: } 0.2-0.6 \mathrm{~mL} \\
\text { of saline }\end{array}$ & Visual Analogue Scale (VAS) & 6 months & $\begin{array}{l}\text { The overall median VAS score for the BTX-treated } \\
\text { group was } 8.9 \text { compared with } 7.2 \text { for the placebo group } \\
(p=0.003) \text {, indicating enhanced healing and improved } \\
\text { cosmesis of the experimentally immobilized scars. }\end{array}$ \\
\hline $\begin{array}{l}\text { Wilson [22], } \\
2006\end{array}$ & $\begin{array}{l}\text { Prospective, } \\
\text { single-arm }\end{array}$ & $\begin{array}{l}55 \text { (15 dropped } \\
\text { out) }\end{array}$ & $\begin{array}{l}\text { BTX was injected once at the } \\
\text { end of the operation. BTX } \\
\text { concentration: } 10 \mathrm{IU} / \mathrm{mL} \text {; } \\
\text { Injection dose: } 1.5 \mathrm{IU} \text { per cm } \\
\text { of wound length. }\end{array}$ & $\begin{array}{l}\text { Objective assessment } \\
\text { Subjective assessment }\end{array}$ & $12-16$ months & $\begin{array}{l}\text { The outcome was considered highly satisfactory in } \\
36 \text { patients }(90 \%) \text {. Thirty patients rated the } \\
\text { improvement as marked }(75 \%) \text {, six rated it as } \\
\text { significant }(15 \%) \text {, and four rated it as unchanged }(10 \%) \text {. } \\
\text { In } 3 \text { cases }(7.5 \%) \text {, the scars re-widened, while in one } \\
\text { case }(2.5 \%) \text {, residual scar depression persisted. }\end{array}$ \\
\hline
\end{tabular}

BTX: Onabotulinum toxin unless otherwise stated. 


\subsection{BTX in Rosacea and Facial Flushing}

Rosacea is a common inflammatory dermatosis characterized by persistent erythema, telangiectasia, papules, pustules, and facial flush. Oral medication, topicals, and laser therapy are routinely performed but often fail to relieve the facial flush. Persistent facial flushing is also a troublesome menopausal symptom.

A number of reports demonstrate the possible action of BTX on rosacea and menopausal hot flashes [23-26] (Table 3). In a prospective pilot study [23], the effect of BTX on the Dermatology Life Quality Index (DLQI) of patients with facial flushing was examined. BTX was injected once up to a total dose of 30 units on the cheeks which led to a significant decrease in DLQI at 2 months follow-up. Odo et al. [26] reported BTX (6.2 IU of abo-BTX per injection point, 40 points over the face, chest, neck, and scalp) to significantly reduce the mean number of menopausal hot flashes at day 60 . The effect of abo-BTX was also investigated in 15 patients with rosacea. 15-45 IU of BTX was injected to the face which resulted in a statistically significant improvement in erythema at 3 months follow-up [24]. Adverse effects were rarely reported in the studies.

One possible mechanism by which BTX improves flushing is the potent blockade of acetylcholine release from autonomic peripheral nerves of the cutaneous vasodilatory system $[27,28]$. It is also well-known that BTX inhibits the release of inflammatory mediators such as substance P and calcitonin gene-related peptide (CGRP) [29]. The reduction and control of local skin inflammation may allow the erythema to fade out.

Larger, controlled, randomized studies are warranted to determine the optimal dose and duration of BTX activity on rosacea and facial flushing. BTX injection for facial flushing has additional benefits as it also improve the fine lines and wrinkles by diminishing the pull of the facial depressors.

\subsection{BTX in Postherpetic Neuralgia}

Postherpetic neuralgia (PHN) is the most frequent chronic complication of herpes zoster and the most common neuropathic pain resulting from infection. It is conventionally defined as dermatomal pain (usually a score of 40 or higher on a Likert scale ranging from 0-no pain to 100-worst possible pain), persisting at least 90 days after the appearance of the acute herpes zoster rash. PHN causes considerable suffering and results in a health care burden at both the individual and societal levels [30].

Treatment approaches include nonsteroidal anti-inflammatory drugs, gabapentin, opioids, and tricyclic antidepressants as well as topical anesthetics and capsaicin cream, but pain can be resistant to all of these drugs.

A number of reports have been made on the efficacy of BTX in PHN [31-33] (Table 4). Xiao et al. [33] performed a randomized, double-blind, placebo-controlled study on 60 PHN patients with the following arms: the BTX group, the $0.5 \%$ lidocaine group, and the $0.9 \%$ saline group. All patients were treated once (as for BTX, a dose of $200 \mathrm{IU}$ at maximum), and were followed-up for 3 months. The BTX treated patients were found to have the most significant improvement in Visual Analog Scale (VAS) and sleep quality compared to those of the other two groups. Apalla et al. [32] also performed a RCT where $30 \mathrm{PHN}$ patients received either BTX (200 IU in total) or placebo. BTX patients showed a significant reduction in VAS pain scores as well as the sleep scores which lasted for approximately 16 weeks. In a prospective study, Ding et al. [31] treated 58 PHN with BTX (50 to $100 \mathrm{IU}$ in total) to find promising results (reduced frequency of pain attacks, lower pain severity, reduction in the quantity of painkillers consumed by patients) with very few adverse reactions.

The mechanism involved in the pain-relieving effect of BTX is still unclear, but it is thought that both the peripheral and central mechanism play a role [33]. The peripheral effects of BTX injection come through the inhibition of neuropeptide release from the peripheral nociceptive nerves [34,35]. In addition, BTX has been suggested to exert central nervous system (CNS) effects through axonal transport to the CNS after peripheral application [36,37].

Although promising, cost would be one of the main considerations to BTX use in PHN. Also, unlike other therapeutic modalities, BTX induces antitoxin antibodies which can limit the clinical effectiveness of the drug after repetitive, long-term use. 
Table 3. Representative studies of BTX in rosacea and facial flushing.

\begin{tabular}{|c|c|c|c|c|c|c|}
\hline $\begin{array}{l}\text { First Author } \\
\text { [Ref.], Year }\end{array}$ & Type of Study & $n$ & Treatment Regimen & Outcome Measures & Follow-Up & Results (Including Adverse Effects) \\
\hline $\begin{array}{l}\text { Eshghi [23], } \\
2016\end{array}$ & $\begin{array}{l}\text { Prospective single } \\
\text { arm (BTX) }\end{array}$ & 24 & $\begin{array}{l}\text { A single treatment with BTX. } 1 \text { IU of BTX } \\
\text { was injected intracutaneously in every } \\
\text { square cm, to a total dose of } 30 \text { IU on both } \\
\text { sides of cheeks. }\end{array}$ & $\begin{array}{l}\text { The Dermatology Life } \\
\text { Quality Index (DLQI) }\end{array}$ & 2 months & $\begin{array}{l}\text { The mean of DLQI improved from } 8.08 \pm 1.17 \\
\text { (baseline) to } 4.5 \pm 1.21 \text { ( } 2 \text { months follow-up) } \\
(p<0.005)\end{array}$ \\
\hline Bloom [24], 2015 & $\begin{array}{l}\text { Prospective, single } \\
\text { arm (Abo-BTX) }\end{array}$ & $\begin{array}{l}25 \text { ( } 15 \text { completed } \\
\text { the study) }\end{array}$ & $\begin{array}{l}\text { A single treatment with abo-BTX. } \\
\text { Abo-BTX concentration: } 100 \mathrm{IU} / \mathrm{mL} \text {; } \\
\text { Injected dose: } 15-45 \mathrm{IU} \text { to the nose, cheeks, } \\
\text { forehead, and chin }\end{array}$ & $\begin{array}{l}\text { Facial erythema assessed by } \\
\text { a non-treating physician } \\
\text { using a standardized grading } \\
\text { system (0-3) }\end{array}$ & 3 months & $\begin{array}{l}\text { The treatment resulted in statistically } \\
\text { significant improvement in erythema grade at } \\
1(p<0.05), 2(p<0.001) \text {, and } 3 \text { months } \\
(p<0.05) \text { after treatment when compared } \\
\text { with baseline. }\end{array}$ \\
\hline $\begin{array}{l}\text { Geddoa [25], } \\
2013\end{array}$ & $\begin{array}{l}\text { Prospective, single } \\
\text { arm (BTX) }\end{array}$ & $\begin{array}{l}22 \text { (18 included in } \\
\text { the final analysis) }\end{array}$ & $\begin{array}{l}\text { A single treatment with BTX for } 20 \\
\text { patients and two sessions of treatment for } \\
2 \text {. BTX concentration: } 10 \mathrm{IU} / \mathrm{mL} \text {; Injected } \\
\text { dose: } 1-2 \mathrm{IU} / \mathrm{cm}^{2} \text { with maximum total } \\
\text { dose of } 100 \mathrm{IU} \text { (neck and/or chest) }\end{array}$ & $\begin{array}{l}\text { Dermatology Life Quality } \\
\text { Index (DLQI) }\end{array}$ & 4 weeks & $\begin{array}{l}\text { The mean change in DLQI (before-after } \\
\text { treatment) was } 3.56 \pm 4.6 \text {, suggesting a } \\
\text { significant improvement in quality of life at } \\
4 \text { weeks following treatment }(p<0.004)\end{array}$ \\
\hline Odo [26], 2011 & $\begin{array}{l}\text { RCT (Abo-BTX vs. } \\
\text { saline) }\end{array}$ & $\begin{array}{l}60 \text { women with } \\
\text { menopausal hot } \\
\text { flushes } \\
\text { Group BTX: } 30 \\
\text { (25 completed) } \\
\text { Group Control: } 30 \\
\text { (23 completed) }\end{array}$ & $\begin{array}{l}\text { A single treatment with either abo-BTX or } \\
\text { saline. Group BTX: Abo-BTX } \\
\text { concentration: } 500 \mathrm{IU} / 3.2 \mathrm{~mL} \text {; Injected } \\
\text { dose: } 6.2 \mathrm{IU} \text { at each selected point in the } \\
\text { skin ( } 40 \text { injection points to the face, chest, } \\
\text { neck, and scalp) } \\
\text { Group Control: saline solution injected at } \\
\text { a volume of } 0.04 \mathrm{~mL} \text { per injection point }\end{array}$ & $\begin{array}{l}\text { Intensity of sweating, } \\
\text { number of hot flashes, and } \\
\text { Starch-Iodine test. } \\
\text { Number of women reporting } \\
\text { episodes of night sweating } \\
\text { and mood changes }\end{array}$ & 6 months & $\begin{array}{l}\text { The sweating and hot flashes were less severe } \\
\text { than before abo-BTX treatment, especially at } \\
2 \text { months follow-up; In the control group, } \\
\text { there was no significant difference in mean } \\
\text { intensity of sweating or in the mean number } \\
\text { of hot flashes. } \\
\text { Other menopausal symptoms such as night } \\
\text { sweats were found better } 2 \text { months after } \\
\text { abo-BTX treatment than in the control group } \\
(p<0.001) \text {. }\end{array}$ \\
\hline
\end{tabular}

BTX: Onabotulinum toxin unless otherwise stated, Abo-BTX: Abobotulinum toxin. 
Table 4. Representative studies of BTX in postherpetic neuralgia (PHN).

\begin{tabular}{|c|c|c|c|c|c|c|}
\hline $\begin{array}{l}\text { First Author } \\
\text { [Ref.], Year }\end{array}$ & Type of Study & $n$ & Treatment Regimen & Outcome Measures & Follow-Up & Results (Including Adverse Effects) \\
\hline Ding [31], 2017 & $\begin{array}{l}\text { Prospective, single } \\
\text { arm (BTX) }\end{array}$ & 58 & $\begin{array}{l}\text { A single session of treatment } \\
\text { was performed. BTX } \\
\text { concentration: } 4 \mathrm{IU} / \mathrm{mL} \text {; } \\
\text { Injection dose: } 50-100 \mathrm{IU} \\
\text { in total }\end{array}$ & $\begin{array}{l}\text { Pain severity (VAS) } \\
\text { Neuropathy pain scale (NPS) } \\
\text { Quality of Life Scale (SF-36) } \\
\text { PHN seizure severity, seizure } \\
\text { duration, and frequency } \\
\text { of attacks. } \\
\text { The use of painkillers }\end{array}$ & 6 months & $\begin{array}{l}\text { At } 6 \text { months follow-up, a significant decrease in } \\
\text { seizure frequency, seizure duration, VAS score, } \\
\text { NPS score, SF- } 36 \text { score and the required amount of } \\
\text { painkiller was observed ( } p<0.05) \text {. } \\
\text { After BTX injection, } 4 \text { patients complained of pain } \\
\text { around the injection area which disappeared within } \\
\text { a week. }\end{array}$ \\
\hline Apalla [32], 2013 & $\begin{array}{l}\text { Double-blinded RCT } \\
\text { (BTX vs. saline) }\end{array}$ & $\begin{array}{l}\text { BTX group: } 15 \\
\text { Control group: } 15\end{array}$ & $\begin{array}{l}\text { BTX group: A single } \\
\text { treatment delivered. BTX } \\
\text { concentration: } 25 \mathrm{IU} / \mathrm{mL} ; \\
\text { Injection dose: each patient } \\
\text { received } 40 \text { injections in total } \\
\text { (5 IU/point). } \\
\text { Control group: A single } \\
\text { treatment with saline. }\end{array}$ & $\begin{array}{l}\text { Pain severity (VA) } \\
\text { Quality of sleep }\end{array}$ & 4 months & $\begin{array}{l}\text { Thirteen patients from the experimental arm } \\
\text { achieved at least } 50 \% \text { reduction in VAS score, } \\
\text { compared with none of the placebo group }(p<0.001) \text {. } \\
\text { BTX patients showed significant reduction in VAS } \\
\text { pain scores between baseline and week 2, which } \\
\text { persisted for a median period of } 16 \text { weeks. BTX } \\
\text { patients showed significant reduction in sleep scores } \\
\text { between baseline and week 2, which remained } \\
\text { unchanged until week } 16(p<0.001) \text {. } \\
\text { Treatment was well-tolerated. }\end{array}$ \\
\hline Xiao [33], 2010 & $\begin{array}{l}\text { Double-blinded RCT } \\
\text { (BTX vs. 0.5\% } \\
\text { lidocaine vs. saline) }\end{array}$ & $\begin{array}{l}\text { BTX group: } 20 \text { (19 } \\
\text { completed) } \\
\text { Lidocaine group: } 20 \\
\text { (19 completed) } \\
\text { Control group: } 20 \\
\text { (18 completed) }\end{array}$ & $\begin{array}{l}\text { BTX group: A single } \\
\text { injection. BTX concentration: } \\
5 \mathrm{IU} / \mathrm{mL} ; \text { Injection dose: } \\
200 \mathrm{IU} \text { at maximum. } \\
\text { Lidocaine group: A single } \\
\text { session of treatment of the } \\
\text { same volume as BTX. } \\
\text { Control group: A single } \\
\text { injection of the same volume } \\
\text { as BTX }\end{array}$ & $\begin{array}{l}\text { Visual Analogue Scale (VAS) } \\
\text { Quality of Life } \\
\text { Percent of Opioid use }\end{array}$ & 3 months & $\begin{array}{l}\text { Compared with pretreatment, VAS pain scores } \\
\text { decreased at day } 7 \text { and } 3 \text { months posttreatment in all } \\
3 \text { groups. However, the VAS pain scores of the BTX } \\
\text { group decreased more significantly compared with } \\
\text { lidocaine and placebo groups at day } 7 \text { and } 3 \text { months } \\
\text { posttreatment }(p<0.01) \text {. Sleep time improved in all } \\
3 \text { groups but was most significant in the BTX group } \\
\text { compared with the lidocaine and placebo groups } \\
(p<0.01) \text {. The percentage of subjects using opioids } \\
\text { posttreatment in the BTX was the lowest }(21.1 \%), \\
\text { compared with the lidocaine (52.6\%) and placebo } \\
(66.7 \%) \text { groups }(p<0.01) \text {. }\end{array}$ \\
\hline
\end{tabular}

BTX: Onabotulinum toxin unless otherwise stated, PHN: post-herpetic neuralgia. 


\subsection{BTX in Pruritus}

Pruritus (also known as itch) is an unpleasant sensation of the skin leading to the desire to scratch. Among the 4 subtypes (pruriceptive, neurogenic, neuropathic, and psychogenic itch), the pruriceptive itch is a peripherally induced pruritus arising from the skin and mucosa and is often seen in dermatological disease.

A number of reports have been made on the efficacy of BTX in pruriceptive pruritus [38-40] (Table 5). Recalcitrant pruritus is a hallmark of lichen simplex, a localized variant of atopic dermatitis. In an open pilot study [40], BTX (abo-BTX, 20-80 IU) was injected intradermally into 5 circumscribed lichenoid lesions with recalcitrant pruritus. Within a week, all patients reported to have noticeable alleviation of itching and at 12 weeks, all were still free from the uncontrollable urge to scratch. Itch is also a common and well-recognized problem in burns [38]. Nine patients with recalcitrant itching secondary to burns were treated with BTX (dosage not specified) where the burn itch fell to 0 out of 10 in 4 weeks. The average duration of symptom free period was reported as nine months.

As clinical evidence has revealed the antipruritic effect of BTX, Arendt-Nielsen et al. [39], investigated the effect of subcutaneous administration of BTX on experimentally histamine-induced itch in human skin. In this double-blind, placebo-controlled study, 14 healthy men received BTX and isotonic saline on the volar surface of either forearm. Histamine prick tests were performed four times at the treatment sites (before treatment, and days 1,3, and 7 after treatment) where BTX reduced the histamine-induced itch intensity, and itch area compared with saline at all time points.

Several possible mechanisms can be responsible for the reduction of pruriceptive itch. Acetylcholine mediates itch in pruritic skin conditions such as atopic dermatitis [41] and BTX inhibits the release of acetylcholine from presynaptic vesicles [42]. BTX is also known to interact with molecules associated with itch and flare such as substance P (releases histamine via the activation of mast cells, promotes vasodilation) and CGRP (a potent vasodilator) [36,43-45]. BTX inhibits the release of such mediators, thus reducing the sensation of itch. Lastly, BTX has also been shown to stabilize mast cells and inhibit their degranulation [46].

Pruritogenic pruritus is usually accompanied by skin inflammation. Since BTX is capable of reducing neurogenic inflammation [29], it is natural to expect improvement of the primary skin disease (e.g., atopic dermatitis, psoriasis) as well, which has in fact been reported through animal studies [47,48], human studies [49] and case reports [50,51]. Although promising in pruritogenic itch (and also in inflammatory dermatoses), we feel that BTX would be best used as an adjunct to conventional therapy. It should be applied focally, considering that the product can induce muscle weakening.

\subsection{BTX in Dermatological Conditions Associated with Hyperhidrosis}

A number of skin disease are caused by and/or have symptoms that are exacerbated by hyperhidrosis, a condition that can be treated successfully with BTX.

Pompholyx or dyshidrotic eczema is a common vesiculo-bullous disease of the palms and/or soles. A hallmark of this disease is its tendency to relapse in response to various provoking factors which includes wet work, occlusion and hyperhidrosis. An intra-individual study of 10 patients [52] (Table 6) investigated the use of BTX (mean dose of $162 \mathrm{IU}$ per palm) for pompholyx, using the using the untreated site as control. $70 \%$ of patients reported a marked improvement of both sweating and itching on the treated site after 6 weeks. In another side-by-side trial [53], dyshidrotic hand eczema was treated with BTX (100 IU per palm) as an adjunct to topical steroids. Six patients who completed the study were found to have improved symptoms of pompholyx and reduced number of relapses by BTX injection.

The anhidrotic effect of BTX in pompholyx can be explained by its action on smooth muscles surrounding the sweat glands and through the inhibition of acetylcholine release. Inhibition of substance $P$ release also explains the reduction in pruritus $[54,55]$.

Hidradenitis suppurativa (HS) is a chronic inflammatory dermatosis of the apocrine glands which typically affects the axillae and groin. Patients afflicted by HS have severe discomfort and treatment is 
extremely challenging. It is well-known that a moist environment in folds, especially in the axilla and groin, provides ideal conditions for the flourishing of bacteria and is a precipitating factor of HS.

In 2005, HS on the axillae was first reported to be successfully treated with BTX (abo-BTX, 250 IU) with 10 months of complete remission [56] (Table 6). Khoo et al. [57] also confirmed the efficacy of BTX in HS where a 46-year-old woman with Hurley stage 2 HS responded well to axillary BTX treatment (50 IU per side) with a remission period of 12 months. The patient had been recalcitrant to conventional treatments and also underwent surgical drainage.

The exact mechanism by which BTX affects the disease process in HS is unclear but it is likely that the effect of BTX on sweat production reduces the population of skin flora and its potential inflammatory effect [56,57]. A second hypothesis is that by inhibiting apocrine secretion, BTX prevents the rupture and spread of follicular material from the pilosebaceous unit [57].

BTX has been studied in inverse psoriasis (Table 6) which is also thought to be exacerbated by excessive sweating. A pilot study of 15 patients with flexural psoriasis [49] showed that 50-100 IU of BTX improved subjective symptoms and objective photographic evidence of disease in $87 \%$ of patients at 2, 4, and 12 weeks follow-up. It is hypothesized that the beneficial effects of BTX in inverse psoriasis is largely due to the reduction of local sweating in folds [49]. Patients with psoriasis are also known to have a higher concentration of substance P receptors in their skin $[58,59]$, meaning that BTX can reduce pruritus and vasodilation by inhibiting neuropeptide liberation (and preventing substance $P$ binding to multiple receptors).

Hailey-Hailey disease is an autosomal dominant acantholytic disorder with mutation of the ATP2C1 gene, clinically manifesting as macerated flexural erythema. Heat and sweat aggravate the disease, worsening the discomfort and pruritic symptoms.

Several case reports [60,61] (Table 6) have evidenced improvement of Hailey-Hailey disease with the use of BTX (50-125 IU per side). In one study, the effect of BTX was found to be comparable to that of laser ablation and dermabrasion [61].

BTX can rationally ameliorate the symptoms of Hailey-Hailey disease via its inhibition of acetylcholine and substance P release from the nerve endings [54,55] (Table 6). Although more clinical evidence is needed to prove effectiveness, BTX may be considered as a possible treatment modality for Hailey-Hailey disease recalcitrant to conventional treatment.

\subsection{BTX in Oily Skin}

Sebum contributes to the delivery of fat-soluble antioxidants to the skin surface and has antimicrobial activity, thereby functioning as a skin barrier. However, excess sebum blocks the pores, provides nourishment to bacteria, and can result in skin inflammation (e.g., acne, seborrheic dermatitis).

Recently, insights into the effect of BTX on sebum production have been published [62,63] (Table 7). Min et al. [62] randomly assigned 42 volunteers with forehead wrinkles to receive 10 or 20 units of BTX, which was administered in five standard injection sites. Treatment with BTX exhibited significant sebum reduction at the injection site of both groups, with a sebum gradient surrounding the injection point. The efficacy did not improve significantly with higher injection doses and the sebum production recovered to normal levels at 16-week follow-up for both treatment groups. Rose and Goldberg [63] also evaluated the safety and efficacy of BTX on the oily skin of 25 subjects. A 10-point injection was made with BTX (abo-BTX, total amount of 30-45 IU) on the forehead to find significantly lower sebum production and high patient satisfaction.

The mechanism by which intradermal BTX injection results in decreased sebum production is not entirely clear because the role of the nervous system and acetylcholine on sebaceous glands is not well defined. However, it is most likely that the arrector pili muscles and the local muscarinic receptors in the sebaceous glands are targets for the neuro-modulatory effects of BTX. Li et al. [64] demonstrated that nicotinic acetylcholine receptor $\alpha 7$ (nAchR $\alpha 7)$ is expressed in human sebaceous glands in vivo, and acetylcholine signal increased lipid synthesis in vitro in a dose-dependent manner. Further study is needed to determine the best candidates, optimal injection techniques and doses. 
Table 5. Representative studies of BTX in itch.

\begin{tabular}{|c|c|c|c|c|c|c|}
\hline $\begin{array}{l}\text { First Author } \\
\text { [Ref.], Year }\end{array}$ & Type of Study & $n$ & Treatment Regimen & Outcome Measures & Follow-Up & Results (Including Adverse Effects) \\
\hline $\begin{array}{l}\text { Akhtar [38], } \\
2012\end{array}$ & $\begin{array}{l}\text { Prospective, single } \\
\text { arm (BTX) }\end{array}$ & 9 & $\begin{array}{l}\text { Treatment with BTX once on } \\
\text { the burn scar. BTX } \\
\text { concentration: } 10-25 \mathrm{IU} / \mathrm{mL} \text {; } \\
\text { Injection dose: not stated }\end{array}$ & Severity of itch (0-10 scale) & $\begin{array}{l}11.3 \text { months on } \\
\text { average }\end{array}$ & $\begin{array}{l}\text { On average, the burn covered } 24 \% \text { of the total body surface } \\
\text { area and } 87.5 \% \text { of patients rated their burn itch as being } \\
\text { severe ( }>7 \text { on the itch scale). Following the administration } \\
\text { of BTX, this fell to } 0 \text { out of } 10 \text { in } 4 \text { weeks. The average } \\
\text { duration of symptom free period was } 9 \text { months } \\
\text { (3-18 months). }\end{array}$ \\
\hline $\begin{array}{l}\text { Gazerani [39], } \\
2009\end{array}$ & $\begin{array}{l}\text { Double-blind, split } \\
\text { arm, RCT (BTX vs. } \\
\text { saline) }\end{array}$ & 14 & $\begin{array}{l}\text { BTX treated arm: } 5 \text { IU of BTX } \\
\text { was injected into the skin once. } \\
\text { Control arm: The same volume } \\
\text { of } 0.9 \% \text { saline as in the BTX } \\
\text { treated side was injected. } \\
\text { After BTX and saline injection, } \\
\text { a skin prick test with histamine } \\
\text { was performed on both sites. }\end{array}$ & $\begin{array}{l}\text { Itch ratings ( } 0-10 \text { scale), } \\
\text { itch area, neurogenic } \\
\text { inflammation (visible flare } \\
\text { area) } \\
\text { Blood flow (Laser Doppler } \\
\text { imaging) } \\
\text { Cutaneous temperature } \\
\text { (Infrared thermography }\end{array}$ & 1 week & $\begin{array}{l}\text { BTX reduced the histamine-induced itch intensity } \\
(p<0.001) \text {, and itch area }(p=0.011) \text { compared with saline } \\
\text { at all time points after treatment. The duration of itch was } \\
\text { also shorter for BTX treated areas }(p<0.001) \text {, with a peak } \\
\text { effect at day 7. The flare area was smaller in the BTX } \\
\text { treated arm compared with the saline treated arm at all } \\
\text { time points after treatment }(p=0.002) \text {. Findings from blood } \\
\text { flow }(p<0.001) \text {, and temperature measurements }(p<0.001) \text {, } \\
\text { clearly showed suppressive effects of BTX on vasomotor } \\
\text { reactions, with the maximal effect on day } 3 \text { and } 7 \text {. }\end{array}$ \\
\hline $\begin{array}{l}\text { Heckmann [40], } \\
2002\end{array}$ & $\begin{array}{l}\text { Prospective, single } \\
\text { arm (Abo-BTX) }\end{array}$ & 4 & $\begin{array}{l}\text { Abo-BTX was injected to a total } \\
\text { of } 6 \text { lichen simplex chronicus } \\
\text { (LSC) patches once. Abo-BTX } \\
\text { concentration: } 100 \mathrm{IU} / \mathrm{mL} \text {; } \\
\text { Injection dose: } 20-80 \mathrm{IU} \text {. }\end{array}$ & $\begin{array}{l}\text { Sensation of pruritus } \\
\text { (VAS 0-10) }\end{array}$ & 4 months & $\begin{array}{l}\text { After a week, all patients reported a noticeable alleviation } \\
\text { of itching. Three patients felt no more itching at all; in one } \\
\text { patient pruritus was reduced to less than } 50 \% \text { according to } \\
\text { the VAS used before and after treatment. After } 4 \text { weeks, } \\
5 \text { of } 6 \text { lesions had cleared without any other treatment. } \\
\text { After } 12 \text { weeks, } 3 \text { patients were still free of symptoms. } \\
\text { One patient who had one lesion on the shin developed a } \\
\text { new lesion on the dorsum of his foot which was cleared in } \\
2 \text { weeks after BTX treatment. }\end{array}$ \\
\hline
\end{tabular}

BTX: Onabotulinum toxin unless otherwise stated, Abo-BTX: abobotulinumtoxin, VAS: Visual Analogue Scale. 
Table 6. BTX in dermatologic disease associated with hyperhidrosis.

\begin{tabular}{|c|c|c|c|c|c|c|}
\hline $\begin{array}{l}\text { First Author } \\
\text { [Ref.], Year }\end{array}$ & Type of Study & $n$ & Treatment Regimen & Outcome Measures & Follow-Up & Results (Including Adverse Effects) \\
\hline \multicolumn{7}{|l|}{ Pompholyx } \\
\hline $\begin{array}{l}\text { Swartling [52], } \\
2002\end{array}$ & $\begin{array}{l}\text { A side-by-side } \\
\text { prospective } \\
\text { controlled trial (BTX } \\
\text { vs. no treatment) }\end{array}$ & 10 & $\begin{array}{l}\text { BTX group: BTX was injected once. BTX } \\
\text { concentration: } 100 \mathrm{IU} / \mathrm{mL} ; \text { Injection dose: } \\
\text { a mean of } 162 \text { IU. } \\
\text { Control group: No treatment. }\end{array}$ & $\begin{array}{l}\text { Effect of treatment } \\
\text { (5-point scale) } \\
\text { VAS for itch Disease } \\
\text { activity score Extent } \\
\text { of the dermatitis }\end{array}$ & 5-6 weeks & $\begin{array}{l}\text { In the self-assessment, } 7 \text { of the } 10 \text { patients in the } \\
\text { study experienced good or very good effect of the } \\
\text { treatment. After injection with BTX, the VAS score } \\
\text { for itching decreased by } 39 \% \text { on the treated side } \\
\text { compared to an increase by } 52 \% \text { on the } \\
\text { untreated side. } \\
\text { Comparing treated vs. untreated sides, it was } \\
\text { found that with BTX injection, a decrease in the } \\
\text { disease activity score ( } 54 \% \text { vs. } 29 \%) \text {, occurrence of } \\
\text { vesicles ( } 74 \text { vs. } 27) \text {, infiltration ( }(54 \text { vs. } 18) \text {, erythema } \\
\text { (53 vs. } 30) \text {, and extent of the disease (58 vs. } 31 \text { ). } \\
\text { No changes or only minor changes were seen in the } \\
\text { objective parameters of scaling, crusting, } \\
\text { and excoriations. }\end{array}$ \\
\hline Wollina [53], 2002 & $\begin{array}{l}\text { A side-by-side } \\
\text { prospective controlled } \\
\text { trial (BTX vs. control) }\end{array}$ & $\begin{array}{l}8 \text { ( } 6 \text { completed } \\
\text { the study) }\end{array}$ & $\begin{array}{l}\text { Topical steroid was applied to both hands } \\
\text { in combination with BTX on one hand and } \\
\text { no additional treatment on the other. } \\
\text { A single injection of BTX was given. BTX } \\
\text { concentration: } 50 \text { IU } / \mathrm{mL} \text {; BTX was } \\
\text { injection in aliquots of } 5 \text { IU per point; } \\
\text { Injection dose: Not mentioned. }\end{array}$ & $\begin{array}{l}\text { Dyshidrotic Eczema } \\
\text { Area and Severity } \\
\text { Index (DASI) }\end{array}$ & 8 weeks & $\begin{array}{l}\text { Six patients completed the study. The mean DASI } \\
\text { score changed from } 28 \text { to } 17 \text { with topical therapy } \\
\text { alone and from } 36 \text { to } 3 \text { with adjuvant BTX }(p<0.01) \text {. } \\
\text { Itching and vesicles were inhibited earlier when } \\
\text { using the combination of steroids and BTX. There } \\
\text { was one relapse in the steroid group and none in } \\
\text { the BTX group. }\end{array}$ \\
\hline \multicolumn{7}{|c|}{ Hidradenitis suppurativa } \\
\hline Khoo [57], 2014 & Case report (BTX) & $\begin{array}{l}3 \text { (only one } \\
\text { described in } \\
\text { detail) }\end{array}$ & $\begin{array}{l}\text { Over the course of } 3 \text { years, a Hurley Stage } \\
\text { II HS patient received } 4 \text { BTX treatments. } \\
50 \text { IU of BTX administered to each axilla } \\
\text { per treatment. BTX concentration: } \\
25 \mathrm{IU} / \mathrm{mL}\end{array}$ & & & $\begin{array}{l}\text { The patient showed good clinical response within } \\
3 \text { months of her first treatment, and, following her } \\
\text { second treatment, went into clinical remission. } \\
\text { She was still in remission when discharged from } \\
\text { follow-up } 1 \text { year after her fourth treatment. }\end{array}$ \\
\hline O'Reilly [56], 2005 & $\begin{array}{l}\text { Case report } \\
\text { (Abo-BTX) }\end{array}$ & 1 & $\begin{array}{l}\text { BTX was injected once to both axilla. } \\
\text { Injection dose: } 250 \text { IU of abo-BTX in total. }\end{array}$ & & & $\begin{array}{l}\text { There was no evidence of active inflammation on } \\
\text { follow-up at a fortnight after administration. } \\
\text { The patient had complete remission of symptoms } \\
\text { until approximately } 10 \text { months later, when the first } \\
\text { symptoms of mild inflammation re-appeared. }\end{array}$ \\
\hline
\end{tabular}


Table 6. Cont

\begin{tabular}{|c|c|c|c|c|c|c|}
\hline $\begin{array}{l}\text { First Author } \\
\text { [Ref.], Year }\end{array}$ & Type of Study & $n$ & Treatment Regimen & Outcome Measures & Follow-Up & Results (Including Adverse Effects) \\
\hline \multicolumn{7}{|l|}{ Psoriasis } \\
\hline Zanchi [49], 2008 & $\begin{array}{l}\text { Prospective, } \\
\text { single-arm (BTX) }\end{array}$ & 15 & $\begin{array}{l}\text { BTX was injected once to the inverse } \\
\text { psoriasis sites. BTX concentration: } \\
20 \mathrm{IU} / \mathrm{mL} \text {; Dose injected: } 50-100 \mathrm{IU} \\
\text { in total. }\end{array}$ & $\begin{array}{l}\text { Photographic } \\
\text { assessment of the } \\
\text { psoriatic area } \\
\text { Subjective } \\
\text { symptomatology } \\
\text { (10-point VAS) }\end{array}$ & 12 weeks & $\begin{array}{l}\text { The location of the psoriasis was as follows: armpits } \\
(7 \text { patients), sub-mammary sulcus (6), intergluteal } \\
\text { folds (7), inguinal folds ( } 5 \text { ) and umbilicus (1). } \\
\text { Subjective symptomatology according to the } \\
10 \text {-point VAS scale improved in all patients. Mean } \\
\text { VAS scores were } 9.1 \text { at the pre-treatment } \\
\text { assessment, with post-treatment mean scores of } 4.2 \\
\text { after } 2 \text { weeks, } 2.1 \text { after } 4 \text { weeks and } 2.4 \text { after } \\
12 \text { weeks. } \\
\text { Erythema extension, intensity and infiltration } \\
\text { improved in } 13 \text { of } 15 \text { patients ( } 87 \% \text { ). The change in } \\
\text { the erythematous area was evident from the first } \\
\text { post-treatment assessment at } 2 \text { weeks and } \\
\text { continued to improve until the assessment at } \\
4 \text { weeks. At the final visit (12 weeks post-treatment), } \\
\text { improvement had been maintained. }\end{array}$ \\
\hline \multicolumn{7}{|c|}{ Hailey-Hailey disease } \\
\hline $\begin{array}{l}\text { Lopez-Ferrer [60], } \\
2012\end{array}$ & Case report (BTX) & 3 & $\begin{array}{l}\text { Case 1: } 80 \text { IU of BTX was first } \\
\text { administered on each axilla. A total of } \\
200 \text { IU of BTX was injected every } \\
2 \text { months for maintenance. } \\
\text { Case 2: } 80-300 \text { IU of BTX was injected to } \\
\text { the groin, below the left breast, the left } \\
\text { axilla, and the side of the neck. } \\
\text { Case 3: } 200-300 \text { IU of BTX was injected to } \\
\text { the axilla, sub-mammary region, } \\
\text { and groin. }\end{array}$ & & & $\begin{array}{l}\text { The Hailey-Hailey disease improved in all } \\
3 \text { patients after BTX injection. BTX injection had to } \\
\text { be repeated for maintaining remission. }\end{array}$ \\
\hline Konrad [61], 2001 & $\begin{array}{l}\text { Case report with } \\
\text { side-by side } \\
\text { comparison (BTX } \\
\text { alone vs. BTX + } \\
\text { Erbium: YAG vs. BTX } \\
\text { + dermabrasion }\end{array}$ & 1 & $\begin{array}{l}\text { Both sub-mammary areas were treated } \\
\text { with BTX at a concentration of } 20 \mathrm{IU} / \mathrm{mL} \text {. } \\
\text { Four days later, surgical (right side) or } \\
\text { laser therapy (left side) was performed on } \\
\text { an area of } 5 \times 5 \mathrm{~cm}^{2} \text {. }\end{array}$ & & & $\begin{array}{l}\text { Wound healing was faster after laser ( } 7 \text { days) } \\
\text { versus dermabrasion (14 days). Those areas treated } \\
\text { only with BTX showed remission of hyperhidrosis } \\
\text { within } 3 \text { days and clearance of Hailey-Hailey } \\
\text { within } 2 \text { weeks. } \\
\text { During a follow-up of } 12 \text { months, no relapse was } \\
\text { seen for dermabrasion, laser ablation and BTX. } \\
\text { Final cosmetic results were comparable. }\end{array}$ \\
\hline
\end{tabular}

BTX: Onabotulinum toxin unless otherwise stated, Abo-BTX: Abobotulinumtoxin, VAS: Visual Analogue Scale. 
Table 7. Representative studies of BTX in oily skin.

\begin{tabular}{|c|c|c|c|c|c|c|}
\hline $\begin{array}{l}\text { First Author } \\
\text { [Ref.], Year }\end{array}$ & Type of Study & $n$ & Treatment Regimen & Outcome Measures & Follow-Up & Results (Including Adverse Effects) \\
\hline Min [62], 2015 & $\begin{array}{l}\text { Prospective (BTX } \\
10 \text { IU vs. BTX } 20 \text { IU) }\end{array}$ & $\begin{array}{l}42 \text { ( } 41 \text { completed the study) } \\
20 \text { received } 10 \text { IU of BTX } \\
20 \text { received } 20 \text { IU }\end{array}$ & $\begin{array}{l}\text { Treatment with BTX once } \\
\text { on the forehead. BTX } \\
\text { concentration: } 40 \mathrm{IU} / \mathrm{mL} \text {; } \\
\text { Injection dose: A final } \\
\text { volume of } 10 \mathrm{IU} \text { or } 20 \mathrm{IU} \\
\text { was injected evenly in } \\
5 \text { injection sites. }\end{array}$ & $\begin{array}{l}\text { Sebum production } \\
\text { (sebumeter) }\end{array}$ & 16 weeks & $\begin{array}{l}\text { Treatment with BTX exhibited significant sebum alteration at } \\
\text { the injection site of both groups (10 IU, } 20 \text { IU), with a sebum } \\
\text { gradient surrounding the injection point. The efficacy did not } \\
\text { improve at higher injection doses, with the four-unit regimen } \\
\text { generally not being more potent than the two-unit regimen. } \\
\text { The sebum production recovered to normal levels at the } \\
\text { 16-week follow-up for both treatment groups, indicating that a } \\
\text { higher dosage ( } 4 \text { units) did not results in a longer duration } \\
\text { until relapse compared with the two-unit dose. }\end{array}$ \\
\hline Rose [63], 2012 & $\begin{array}{l}\text { Prospective, } \\
\text { single-arm (Abo-BTX) }\end{array}$ & 25 & $\begin{array}{l}\text { Abo-BTX was injected once } \\
\text { on the forehead. Abo-BTX } \\
\text { concentration: } 100 \mathrm{IU} / \mathrm{mL} \text {; } \\
\text { Injection dose: A total of } \\
30-45 \text { IU delivered to } \\
10 \text { injection sites. }\end{array}$ & $\begin{array}{l}\text { Sebum production } \\
\text { (sebumeter) } \\
\text { Patient satisfaction } \\
\text { (4-point scale) }\end{array}$ & 3 months & $\begin{array}{l}\text { Treatment with BTX resulted in significantly lower sebum } \\
\text { production at } 1 \text { week and } 1,2 \text {, and } 3 \text { months after injection } \\
(p<0.001) \text {. Twenty-one patients ( } 91 \% \text { ) reported that they were } \\
\text { satisfied (50-75\% improvement) with intradermal BTX as a } \\
\text { treatment for oily skin. }\end{array}$ \\
\hline
\end{tabular}

BTX: Onabotulinum toxin unless otherwise stated, Abo-BTX: abobotulinumtoxin. 


\section{Conclusions}

In this review, we highlighted the promising outcomes of BTX in several off-label indications of interest for dermatologists. There is overwhelming evidence that BTX exhibits biological effects on many human cell types, but much is yet to be learned about the drug and its mechanism of action. Knowing that the skin closely interacts with the nervous system, future studies should investigate the link between BTX and the cutaneous neuroimmune system to better understand its therapeutic potential in dermatology. A consensus on the dose regimen and injection technique is also desirable for standardized treatment. Generally, high doses of BTX were applied, with an average total of 300 IU for hypertrophic scars, 50 IU for scar prevention, 50-100 IU for facial flush/rosacea, $100 \mathrm{IU}$ for PHN, $150 \mathrm{IU}$ for pompholyx, $100 \mathrm{IU}$ for HS, 75 IU for inverse psoriasis and $250 \mathrm{IU}$ for Hailey-Hailey disease. Lastly, with the limitations of BTX treatment (high cost, muscle weakening, risk of tachyphylaxis and production of antibodies), BTX may be optimally used as an adjunct in recalcitrant cases to conventional therapy.

Acknowledgments: This study was supported by the National Research Foundation of Korea (NRF) grant funded by the Korea government (MSIT) (Grant No.: 2017R1C1B5016144) and the 2016 Amore-Pacific grant.

Conflicts of Interest: The authors declare no conflict of interest.

\section{References}

1. Steinhoff, M.; Stander, S.; Seeliger, S.; Ansel, J.C.; Schmeiz, M.; Luger, T. Modern aspects of cutaneous neurogenic inflammation. Arch. Dermatol. 2003, 139, 1479-1488. [CrossRef]

2. Ansel, J.C.; Kaynard, A.H.; Armstrong, C.A.; Olerud, J.; Bunnett, N.; Payan, D. Skin-nervous system interactions. J. Investig. Dermatol. 1996, 106, 198-204. [CrossRef]

3. Berman, B.; Maderal, A.; Raphael, B. Keloids and hypertrophic scars: Pathophysiology, classification, and treatment. Dermatol. Surg. 2017, 43 (Suppl. 1), S3-S18. [CrossRef]

4. Elhefnawy, A.M. Assessment of intralesional injection of botulinum toxin type A injection for hypertrophic scars. Indian J. Dermatol. Venereol. Leprol. 2016, 82, 279-283. [CrossRef]

5. Shaarawy, E.; Hegazy, R.A.; Abdel Hay, R.M. Intralesional botulinum toxin type A equally effective and better tolerated than intralesional steroid in the treatment of keloids: A randomized controlled trail. J. Cosmet. Dermatol. 2015, 14, 161-166. [CrossRef]

6. Xiao, Z.; Zhang, F.; Cui, Z. Treatment of hypertrophic scars with intralesional botulinum toxin type A injections: A preliminary report. Aesthet. Plast. Surg. 2009, 33, 409-412. [CrossRef]

7. Zhibo, X.; Miaobo, Z. Intralesional botulinum toxin type A injection as a new treatment measure for keloids. Plast. Reconstr. Surg. 2009, 124, 275e-277e. [CrossRef] [PubMed]

8. Xiao, Z.; Zhang, M.; Liu, Y.; Ren, L. Botulinum toxin type A inhibits connective tissue growth factor expression in fibroblasts derived from hypertrophic scar. Aesthet. Plast. Surg. 2011, 35, 802-807. [CrossRef] [PubMed]

9. Chen, M.; Yan, T.; Ma, K.; Lai, L.; Liu, C.; Liang, L.; Fu, X. Botulinum toxin type a inhibits alpha-smooth muscle actin and myosin ii expression in fibroblasts derived from scar contracture. Ann. Plast. Surg. 2016, 77, e46-e49. [CrossRef] [PubMed]

10. Jeong, H.S.; Lee, B.H.; Sung, H.M.; Park, S.Y.; Ahn, D.K.; Jung, M.S.; Suh, I.S. Effect of botulinum toxin type a on differentiation of fibroblasts derived from scar tissue. Plast. Reconstr. Surg. 2015, 136, 171e-178e. [CrossRef] [PubMed]

11. Wang, X.; Chen, X.; Xiao, Z. Effects of botulinum toxin type a on expression of genes in keloid fibroblasts. Aesthet. Surg. J. 2014, 34, 154-159. [CrossRef] [PubMed]

12. Viera, M.H.; Amini, S.; Valins, W.; Berman, B. Innovative therapies in the treatment of keloids and hypertrophic scars. J. Clin. Aesthet. Dermatol. 2010, 3, 20-26. [PubMed]

13. Uyesugi, B.; Lippincott, B.; Dave, S. Treatment of painful keloid with botulinum toxin type A. Am. J. Phys. Med. Rehabil. 2010, 89, 153-155. [CrossRef] [PubMed]

14. Lee, B.J.; Jeong, J.H.; Wang, S.G.; Lee, J.C.; Goh, E.K.; Kim, H.W. Effect of botulinum toxin type A on a rat surgical wound model. Clin. Exp. Otorhinolaryngol. 2009, 2, 20-27. [CrossRef] [PubMed] 
15. Wolfram, D.; Tzankov, A.; Pulzl, P.; Piza-Katzer, H. Hypertrophic scars and keloids-A review of their pathophysiology, risk factors, and therapeutic management. Dermatol. Surg. 2009, 35, 171-181. [CrossRef] [PubMed]

16. Zhibo, X.; Miaobo, Z. Botulinum toxin type A affects cell cycle distribution of fibroblasts derived from hypertrophic scar. J. Plast. Reconstr. Aesthet. Surg. 2008, 61, 1128-1129. [CrossRef] [PubMed]

17. Zhibo, X.; Miaobo, Z. Potential therapeutical effects of botulinum toxin type A in keloid management. Med. Hypotheses 2008, 71, 623. [CrossRef] [PubMed]

18. Xiao, Z.; Zhang, F.; Lin, W.; Zhang, M.; Liu, Y. Effect of botulinum toxin type A on transforming growth factor beta 1 in fibroblasts derived from hypertrophic scar: A preliminary report. Aesthet. Plast. Surg. 2010, 34, 424-427. [CrossRef] [PubMed]

19. Kim, Y.S.; Lee, H.J.; Cho, S.H.; Lee, J.D.; Kim, H.S. Early postoperative treatment of thyroidectomy scars using botulinum toxin: A split-scar, double-blind, randomized controlled trial. Wound Repair Regen. 2014, 22, 605-612. [CrossRef] [PubMed]

20. Ziade, M.; Domergue, S.; Batifol, D.; Jreige, R.; Sebbane, M.; Goudot, P.; Yachouh, J. Use of botulinum toxin type A to improve treatment of facial wounds: A prospective randomized study. J. Plast. Reconstr. Aesthet. Surg. 2013, 66, 209-214. [CrossRef] [PubMed]

21. Gassner, H.G.; Brissett, A.E.; Otley, C.C.; Boahene, D.K.; Boggust, A.J.; Weaver, A.L.; Sherris, D.A. Botulinum toxin to improve facial wound healing: A prospective, blinded, placebo-controlled study. Mayo Clin. Proc. 2006, 81, 1023-1028. [CrossRef] [PubMed]

22. Wilson, A.M. Use of botulinum toxin type A to prevent widening of facial scars. Plast. Reconstr. Surg. 2006, 117, 1758-1766. [CrossRef] [PubMed]

23. Eshghi, G.; Khezrian, L.; Alirezaei, P. Botulinum toxin in treatment of facial flushing. Acta Med. Iran 2016, 54, 454-457. [PubMed]

24. Bloom, B.S.; Payongayong, L.; Mourin, A.; Goldberg, D.J. Impact of intradermal abobotulinumtoxin A on facial erythema of rosacea. Dermatol. Surg. 2015, 41 (Suppl. 1), S9-S16. [CrossRef] [PubMed]

25. Geddoa, E.; Matar, H.E.; Paes, T.R. The use of botulinum toxin-a in the management of neck and anterior chest wall flushing: Pilot study. Int. J. Dermatol. 2013, 52, 1547-1550. [CrossRef] [PubMed]

26. Odo, M.E.; Odo, L.M.; Farias, R.V.; Primavera, R.A.; Leao, L.; Cuce, L.C.; Juliano, Y. Botulinum toxin for the treatment of menopausal hot flushes: A pilot study. Dermatol. Surg. 2011, 37, 1579-1583. [CrossRef] [PubMed]

27. Kellogg, D.L., Jr. In vivo mechanisms of cutaneous vasodilation and vasoconstriction in humans during thermoregulatory challenges. J. Appl. Phys. 2006, 100, 1709-1718. [CrossRef] [PubMed]

28. Kellogg, D.L., Jr.; Pergola, P.E.; Piest, K.L.; Kosiba, W.A.; Crandall, M.; Johnson, J.M. Cutaneous active vasodilation in humans is mediated by cholinergic nerve cotransmission. Circ. Res. 1995, 77, 1222-1228. [CrossRef] [PubMed]

29. Carmichael, M.M.; Dostrovsky, J.O.; Charlton, M.P. Peptide-mediated transdermal delivery of botulinum neurotoxin type A reduces neurogenic inflammation in the skin. Pain 2010, 149, 316-324. [CrossRef] [PubMed]

30. Johnson, R.W.; Rice, A.S. Clinical practice. Postherpetic neuralgia. N. Engl. J. Med. 2014, 371, $1526-1533$. [CrossRef] [PubMed]

31. Ding, X.D.; Zhong, J.; Liu, Y.P.; Chen, H.X. Botulinum as a toxin for treating post-herpetic neuralgia. Iran J. Public Health 2017, 46, 608-611. [PubMed]

32. Apalla, Z.; Sotiriou, E.; Lallas, A.; Lazaridou, E.; Ioannides, D. Botulinum toxin a in postherpetic neuralgia: A parallel, randomized, double-blind, single-dose, placebo-controlled trial. Clin. J. Pain 2013, 29, 857-864. [CrossRef] [PubMed]

33. Xiao, L.; Mackey, S.; Hui, H.; Xong, D.; Zhang, Q.; Zhang, D. Subcutaneous injection of botulinum toxin A is beneficial in postherpetic neuralgia. Pain Med. 2010, 11, 1827-1833. [CrossRef] [PubMed]

34. Gazerani, P.; Pedersen, N.S.; Staahi, C.; Drewes, A.M.; Arendt-Nielsen, L. Subcutaneous botulinum toxin type A reduces capsaicin-induced trigeminal pain and vasomotor reactions in human skin. Pain 2009, 141, 60-69. [CrossRef] [PubMed]

35. Gazerani, P.; Staahi, C.; Drewes, A.M.; Arendt-Nielsen, L. The effects of botulinum toxin type A on capsaicin-evoked pain, flare, and secondary hyperalgesia in an experimental human model of trigeminal sensitization. Pain 2006, 122, 315-325. [CrossRef] [PubMed] 
36. Aoki, K.R. Review of a proposed mechanism for the antinociceptive action of botulinum toxin type A. Neurotoxicology 2005, 26, 785-793. [CrossRef] [PubMed]

37. Antonucci, F.; Rossi, C.; Gianfranceschi, L.; Rossetto, O.; Caleo, M. Long-distance retrograde effects of botulinum neurotoxin A. J. Neurosci. 2008, 28, 3689-3696. [CrossRef] [PubMed]

38. Akhtar, N.; Brooks, P. The use of botulinum toxin in the management of burns itching: Preliminary results. Burns 2012, 38, 1119-1123. [CrossRef] [PubMed]

39. Gazerani, P.; Pedersen, N.S.; Drewes, A.M.; Arendt-Nielsen, L. Botulinum toxin type A reduces histamine-induced itch and vasomotor responses in human skin. Br. J. Dermatol. 2009, 161, 737-745. [CrossRef] [PubMed]

40. Heckmann, M.; Heyer, G.; Brunner, B.; Plewig, G. Botulinum toxin type A injection in the treatment of lichen simplex: An open pilot study. J. Am. Acad. Dermatol. 2002, 46, 617-619. [CrossRef] [PubMed]

41. Hallett, M. How does botulinum toxin work? Ann. Neurol. 2000, 48, 7-8. [CrossRef]

42. Huang, W.; Foster, J.A.; Rogachefsky, A.S. Pharmacology of botulinum toxin. J. Am. Acad. Dermatol. 2000, 43, 249-259. [CrossRef] [PubMed]

43. Arezzo, J.C. Possible mechanisms of the effects of botulinum toxin on pain. Clin. J. Pain 2002, 18 (Suppl. 6), S125-S132. [CrossRef] [PubMed]

44. McMahon, H.T.; Foran, P.; Dolly, J.O.; Verhage, M.; Wiegant, V.M.; Nicholls, D.G. Tetanus toxin and botulinum toxins type A and B inhibit glutamate, gamma-aminobutyric acid, aspartate, and met-enkephalin release from synaptosomes. Clues to the locus of action. J. Biol. Chem. 1992, 267, 21338-21343. [PubMed]

45. Purkiss, J.; Welch, M.; Doward, S.; Foster, K. Capsaicin-stimulated release of substance P from cultured dorsal root ganglion neurons: Involvement of two distinct mechanisms. Biochem. Pharmacol. 2000, 59, 1403-1406. [CrossRef]

46. Park, T.H. The effects of botulinum toxin A on mast cell activity: Preliminary results. Burns 2013, 39, 816-817. [CrossRef] [PubMed]

47. Han, S.B.; Kim, H.; Cho, S.H.; Chung, J.H.; Kim, H.S. Protective effect of botulinum toxin type A against atopic dermatitis-like skin lesions in NC/Nga mice. Dermatol. Surg. 2017. [CrossRef] [PubMed]

48. Ward, N.L.; Kavlick, K.D.; Diaconu, D.; Dawes, S.M.; Michaels, K.A.; Gilbert, E. Botulinum neurotoxin A decreases infiltrating cutaneous lymphocytes and improves acanthosis in the KC-Tie2 mouse model. J. Investig. Dermatol. 2012, 132, 1927-1930. [CrossRef] [PubMed]

49. Zanchi, M.; Favot, F.; Bizzarini, M.; Piai, M.; Donini, M.; Sedona, P. Botulinum toxin type A for the treatment of inverse psoriasis. J. Eur. Acad. Dermatol. Venereol. 2008, 22, 431-436. [CrossRef] [PubMed]

50. Saber, M.; Brassard, D.; Benohanian, A. Inverse psoriasis and hyperhidrosis of the axillae responding to botulinum toxin type A. Arch. Dermatol. 2011, 147, 629-630. [CrossRef] [PubMed]

51. Gilbert, E.; Ward, N.L. Efficacy of botulinum neurotoxin type A for treating recalcitrant plaque psoriasis. J. Drugs Dermatol. 2014, 13, 1407-1408. [PubMed]

52. Swartling, C.; Naver, H.; Lindberg, M.; Anveden, I. Treatment of dyshidrotic hand dermatitis with intradermal botulinum toxin. J. Am. Acad. Dermatol. 2002, 47, 667-671. [CrossRef] [PubMed]

53. Wollina, U.; Karamfilov, T. Adjuvant botulinum toxin A in dyshidrotic hand eczema: A controlled prospective pilot study with left-right comparison. J. Eur. Acad. Dermatol. Venereol. 2002, 16, 40-42. [CrossRef] [PubMed]

54. Humm, A.M.; Pabst, C.; Lauterburg, T.; Burgunder, J.M. Enkephalin and aFGF are differentially regulated in rat spinal motoneurons after chemodenervation with botulinum toxin. Exp. Neurol. 2000, 161, 361-372. [CrossRef] [PubMed]

55. Ishikawa, H.; Mitsui, Y.; Yoshitomi, T.; Mashimo, K.; Aoki, S.; Mukuno, K.; Shimizu, K. Presynaptic effects of botulinum toxin type A on the neuronally evoked response of albino and pigmented rabbit iris sphincter and dilator muscles. Jpn. J. Opthalmol. 2000, 44, 106-109. [CrossRef]

56. O'Reilly, D.J.; Pleat, J.M.; Richards, A.M. Treatment of hidradenitis suppurativa with botulinum toxin A. Plast. Reconstr. Surg. 2005, 116, 1575-1576. [CrossRef] [PubMed]

57. Khoo, A.B.; Burova, E.P. Hidradenitis suppurativa treated with clostridium botulinum toxin A. Clin. Exp. Dermatol. 2014, 39, 749-750. [CrossRef] [PubMed]

58. Staniek, V.; Doutremepuich, J.; Schmitt, D.; Claudy, A.; Misery, L. Expression of substance P receptors in normal and psoriatic skin. Pathobiology 1999, 67, 51-54. [CrossRef] [PubMed]

59. Nakamura, M.; Toyoda, M.; Morohashi, M. Pruritogenic mediators in psoriasis vulgaris: Comparative evaluation of itch-associated cutaneous factors. Br. J. Dermatol. 2003, 149, 718-730. [CrossRef] [PubMed] 
60. Lopez-Ferrer, A.; Alomar, A. Botulinum toxin A for the treatment of familial benign pemphigus. Actas Dermosifiliogr. 2012, 103, 532-535. [CrossRef] [PubMed]

61. Konrad, H.; Karamfilov, T.; Wollina, U. Intracutaneous botulinum toxin A versus ablative therapy of Hailey-Hailey disease-A case report. J. Cosmet. Laser Ther. 2001, 3, 181-184. [CrossRef] [PubMed]

62. Min, P.; Xi, W.; Grassetti, L.; Trisliana Perdanasari, A.; Torresetti, M.; Feng, S.; Su, W.; Pu, Z.; Zhang, Y.; Han, S.; et al. Sebum production alteration after botulinum toxin type A injections for the treatment of forehead rhytides: A prospective randomized double-blind dose-comparative clinical investigation. Aesthet. Surg. J. 2015, 35, 600-610. [CrossRef] [PubMed]

63. Rose, A.E.; Goldberg, D.J. Safety and efficacy of intradermal injection of botulinum toxin for the treatment of oily skin. Dermatol. Surg. 2013, 39, 443-448. [CrossRef] [PubMed]

64. Li, Z.J.; Park, S.B.; Sohn, K.C.; Lee, Y.; Seo, Y.J.; Kim, C.D.; Kim, Y.S.; Lee, J.H.; Im, M. Regulation of lipid production by acetylcholine signalling in human sebaceous glands. J. Dermatol. Sci. 2013, 72, 116-122. [CrossRef] [PubMed]

(C) 2017 by the authors. Licensee MDPI, Basel, Switzerland. This article is an open access article distributed under the terms and conditions of the Creative Commons Attribution (CC BY) license (http:/ / creativecommons.org/licenses/by/4.0/). 